\title{
Differential expression of the epigenetic methylation-related protein DNMT1 by breast cancer molecular subtype and stromal histology
}

\author{
Eunah Shin ${ }^{1}$, YuKyung Lee ${ }^{2}$ and Ja Seung Koo ${ }^{2^{*}}$
}

\begin{abstract}
Background: We assessed the expression of methylation-related proteins 5-meC, DNMT1, and ISL-1 in breast cancer and evaluated their relationship to clinicopathological factors.

Methods: Immunohistochemical staining for ER, PR, HER-2, Ki-67, 5-meC, DNMT1, and ISL-1 were performed on 348 breast cancer samples in tissue microarray. Samples were subgrouped into luminal A, luminal B, HER-2, or triple-negative breast cancer (TNBC) according to immunohistochemical staining for ER, PR, HER-2, and Ki-67. The tumor stroma was histologically subtyped into desmoplastic, sclerotic, normal-like, or inflammatory type.

Results: Tumor expression of DNMT1 differed by molecular subtype: it was higher in TNBC and lower in luminal A $(p<0.001)$ samples. DNMT1 expression was also related to higher histologic grade, ER negativity, PR negativity, and higher Ki-67 LI ( $p<0.001)$. In western blot, protein expressions of DNMT1 and ISL-1 were higher in TNBC and relatively lower in the remaining subtypes. High tumor expression of DNMT1 was associated with shorter OS in univariate analysis $(p=0.041)$. DNMT1 and 5-meC were differentially expressed by stromal phenotype: 5 -meC was higher in normal-like type and lower in sclerotic type $(p=0.049)$; DNMT1 was higher in inflammatory and lower in sclerotic type $(p<0.001)$.
\end{abstract}

Conclusions: Tumor expression of DNMT1 in breast cancer differed by molecular subtype and stromal histological type. DNMT1 was highly expressed in TNBC and in breast cancer with inflammatory stromal type.

Keywords: Breast cancer, DNA methylation, DNMT1

\section{Background}

One of the most important features differentiating cancer cells from normal cells is insensitivity to growth inhibitory signals. This insensitivity mostly occurs through the inhibition of tumor suppressor genes [1] by DNA hypermethylation. DNA hypermethylation is initiated by DNA methyltransferases (DNMTs) [2]. Genes for the DNMTs identified to date are DNMT1, DNMT2, $D N M T 3 A$, and DNMT3B. DNMT1 is a key maintenance methyltransferase and is the most common methyltransferase in humans. Molecules associated with DNMT1 are 5-methylcytosine $(5-\mathrm{MeC})$ and insulin gene enhancer

\footnotetext{
*Correspondence: kjs1976@yuhs.ac

${ }^{2}$ Department of Pathology, Yonsei University College of Medicine, 50

Yonsei-ro, Seodaemun-gu, Seoul 120-752, South Korea

Full list of author information is available at the end of the article
}

binding protein-1 (ISL-1). DNA methylation occurs when a methyl group is added to the $5^{\prime}$ position of the cytosine ring in $\mathrm{CpG}$ dinucleotides, yielding $5-\mathrm{MeC}$; thus, $5-\mathrm{MeC}$ is the end product of DNA methylation. ISL-1 is a direct target of DNMT1 in breast cancer [3]. Previous studies of epigenetic methylation-related proteins in breast cancer found that expression of DNMT1 and DNMT3a is higher in breast cancer than in benign lesions and the expression is related to breast cancer prognosis [4]. However, breast cancers are heterogeneous tumors with diverse clinical, histological, and molecular features; thus, breast cancer is subgrouped into luminal A, luminal B, HER-2, normal breast-like, and basal-like types by gene profiling analysis $[5,6]$. These molecular subgroups have different molecular, histological, and clinical features and differ in treatment response and prognosis. Breast cancer subtypes 
are expected to have differential expression of epigenetic methylation-related proteins, but studies on this topic have not yet been reported. We assessed the expression of methylation-related proteins 5-meC, DNMT1, and ISL-1 in breast cancer and evaluated their relationships with clinicopathological factors.

\section{Methods}

\section{Patient selection and histological evaluation}

Patients diagnosed with invasive ductal carcinoma, NOS, at Severance Hospital from January 2000 to December 2006 were included. Patients who received preoperative chemotherapy or hormonal therapy were excluded. This study was approved by the Institutional Review Board of Yonsei University Severance Hospital and was exempt from informed consent from patients. Hematoxylin and eosin (H\&E)-stained slides of all cases were reviewed by a breast pathologist (Koo JS). Histological grade was assessed using the Nottingham grading system [7]. Clinicopathological parameters evaluated were patient age at initial diagnosis, lymph node metastasis, tumor recurrence, distant metastasis, and patient survival. Tumor stroma were subgrouped as: (1) desmoplastic type for tumor stroma with cellular fibroblast/myofibroblast proliferation; (2) sclerotic type for tumor stroma of fibrotic collagenous components with little cellular component; (3) normal-like type for stroma with no stromal reaction around tumor cells or for normal breast stroma; and (4) inflammatory type for tumor stroma composed of inflammatory cells such as lymphocytes.

\section{Tissue microarrays}

A representative area showing the tumor and tumor stroma was selected on an H\&E-stained slide and a corresponding spot was marked on the surface of the paraffin block. Using a biopsy needle, the selected area was punched out and a $3-\mathrm{mm}$ tissue core was transferred to a $6 \times 5$ recipient block. Two tissue cores of invasive tumor were extracted to minimize extraction bias. Each tissue core was assigned a unique tissue microarray location number linked to a database containing clinicopathological data.

\section{Immunohistochemistry}

Antibodies used for immunohistochemistry are listed in Table 1. Immunohistochemistry used formalin-fixed, paraffin-embedded 5 - $\mu \mathrm{m}$ tissue sections obtained with a microtome, transferred onto adhesive slides, and dried at $62{ }^{\circ} \mathrm{C}$ for $30 \mathrm{~min}$. After incubation with primary antibodies, immunodetection was performed with biotinylated anti-mouse immunoglobulin followed by peroxidaselabeled streptavidin using a labeled streptavidin-biotin kit with $3,3^{\prime}$-diaminobenzidine chromogen as the substrate. The primary antibody incubation step was omitted
Table 1 Source, clone, and dilution of antibodies

\begin{tabular}{|c|c|c|c|}
\hline Antibody & Company & Clone & Dilution \\
\hline \multicolumn{4}{|c|}{ DNA methylation-related proteins } \\
\hline DNMT1 & Abcam, Cambridge, UK & 2B5 & $1: 200$ \\
\hline 5-mec & Abcam, Cambridge, UK & $33 \mathrm{D} 3$ & $1: 200$ \\
\hline$I S L-1$ & Abcam, Cambridge, UK & Polyclonal & $1: 200$ \\
\hline \multicolumn{4}{|c|}{ Molecular subtype-related proteins } \\
\hline $\mathrm{ER}$ & $\begin{array}{l}\text { Thermo Scientific, San Diego, } \\
\text { CA, USA }\end{array}$ & SP1 & $1: 100$ \\
\hline PR & DAKO, Glostrup, Denmark & PgR & $1: 50$ \\
\hline HER-2 & DAKO, Glostrup, Denmark & Polyclonal & $1: 1500$ \\
\hline Ki-67 & Abcam, Cambridge, UK & MIB & $1: 1000$ \\
\hline
\end{tabular}

in the negative control. Positive control tissue was used as per the manufacturer's recommendation. Slides were counterstained with Harris hematoxylin.

\section{Interpretation of immunohistochemical staining}

Immunohistochemical markers were assessed by light microscopy. A cut-off value of $1 \%$ or more positively stained nuclei was used to define estrogen receptor (ER) and progesterone receptor (PR) positivity [8]. HER-2 staining was analyzed according to the American society of clinical oncology-college of American pathologists guidelines using the following categories: 0 , no immunostaining; $1+$, weak, incomplete membranous staining of less than $10 \%$ tumor cells; $2+$, complete membranous staining, either uniform or weak in at least $10 \%$ of tumor cells; and $3+$, uniform, intense membranous staining in at least $30 \%$ of tumor cells [9]. HER-2 immunostaining was considered positive when strong $(3+)$ membranous staining was observed; samples scored as 0 to $1+$ were regarded as negative. Samples showing 2+ HER-2 expression were evaluated for HER-2 amplification by fluorescent in situ hybridization (FISH).

Immunohistochemical staining for 5-meC, DNMT1, and ISL1 was assessed semiquantitatively by light microscopy [10]. Staining results in malignant cells and stromal cells were assessed as 0 , negative or weak immunostaining in $<1 \%$ of the tumor/stroma; 1 , focal expression in $1-10 \%$ of tumor/stroma; 2 , positive in $11-50 \%$ of tumor/ stroma; and 3, positive in 51-100\% of tumor/stroma. This evaluation was applied to all areas of the tumor in all samples; grade 0 was negative and grades higher than 1 were positive. Positive results were further classified as low (grades 1 and 2) and high (grade 3 ).

\section{Tumor phenotype classification}

We classified breast cancer phenotypes according to immunohistochemical results for ER, PR, HER-2, and 
Ki-67 and FISH results for HER-2 [11]: luminal A type, ER or/and PR positive, HER-2 negative, and Ki-67 LI $<14 \%$; luminal B type (HER-2 negative), ER or/and PR positive, HER-2 negative and Ki-67 LI $\geq 14 \%$; luminal $\mathrm{B}$ type (HER-2 positive), ER or/and PR positive and HER-2 overexpressed or/and amplified; HER-2 overexpression type, ER and PR negative and HER-2 overexpressed or/ and amplified; and TNBC type, ER, PR, and HER-2 negative.

\section{Laser microdissection, protein extraction from FFPE tissues and Western blot}

To acquire tumor, laser microdissection was performed with hematoxylin stained uncovered slides generated by FFPE blocks (LMD 6500, Leica, Wetzlar,Germany). Five cases per each molecular subtype of breast cancer were miscrodissected. Protein extractions from formalin-fixed, paraffin-embedded (FFPE) tissues were performed using the Qproteome FFPE tissue kit (Qiagen, Hilden, Germany). Briefly, three sections from the same block were deparaffinized in xylene and rehydrated in graded series of alcohol. The tissues were mixed with FFPE extraction buffer (EXB), incubated at $100{ }^{\circ} \mathrm{C}$ for $20 \mathrm{~min}$ and at $80^{\circ} \mathrm{C}$ for $2 \mathrm{~h}$ with agitation at $750 \mathrm{rpm}$, and then centrifuged for $15 \mathrm{~min}$ at $14,000 \times g$ at $4{ }^{\circ} \mathrm{C}$. The supernatant containing the extracted proteins were determined by the Bradford assay (Bio-Rad Laboratories, Hercules, CA). An equal amount of protein from each sample extract was separated on SDS-PAGE gels and blotted onto nitrocellulose membranes (Bio-Rad). Western blotting was performed with primary antibodies against Dnmt 1 , Islet 1 , and actin (Abcam, Cambridge, UK), and specific bands were detected using the enhanced chemiluminescence kit (GE Healthcare Life Sciences, Little Chalfont, UK).

\section{Statistical analysis}

Data were analyzed using SPSS for Windows, Version 12.0 (SPSS Inc., Chicago, IL, USA). For determination of statistical significance, Student's t test and Fisher's exact test were used for continuous and categorical variables, respectively. To analyze data with multiple comparisons, a corrected p-value with application of the Bonferroni multiple comparison procedure was used. Statistical significance was set at $\mathrm{p}<0.05$. Kaplan-Meier survival curves and log-rank statistics were used to evaluate time to tumor recurrence and overall survival. Multivariate regression analysis used the Cox proportional hazards model.

\section{Results}

Basal characteristics of breast cancer

Among the 348 breast cancer samples in this study, 162 (42.8\%) were luminal A, 84 (23.7 \%) were luminal B, 27
(9.0 \%) were HER-2 type, and 75 (24.5\%) were TNBC. Upon evaluation of clinicopathologic parameters, histologic grade, KI-67 LI, and stromal phenotype were different according to the molecular subtype with statistical significance $(\mathrm{p}<0.001)$. TNBC was associated with higher histological grade and higher Ki-67 LI than other subtypes (Table 2). Luminal B demonstrated a higher percentage of desmoplastic stromal type than other subtypes, whereas TNBC demonstrated a higher percentage of inflammatory type.

\section{Expression of epigenetic methylation-related proteins in breast cancer}

The epigenetic methylation-related proteins 5-meC and DNMT1 were expressed in both malignant cells and stromal cells, and ISL-1 was expressed only in the malignant cells. Expression analysis of epigenetic methylation-related proteins according to the molecular subtypes revealed that the expression of DNMT1 in malignant cells differs by molecular subtype $(\mathrm{p}<0.001)$ : it was higher in TNBC and lower in luminal A (Table 3 and Fig. 1). Expression of DNMT1 in stromal cells was apparent in TNBC only. Meanwhile, expression analysis of epigenetic methylation-related proteins according to the stromal phenotypes demonstrated that the expressions of 5-meC and DNMT1 in malignant cells differ by stromal phenotype $(\mathrm{p}=0.049$, and $\mathrm{p}<0.001$, respectively): 5-meC expression in malignant cells was highly expressed in normal-like type, with lower expression in sclerotic type. Expression of DNMT1 in malignant cells was higher in inflammatory type and lower in sclerotic type (Table 4 and Fig. 2). Fourteen cases (4\%) disclosed low positive results for 5-meC in the stromal component, in which spindle cells with a negative reaction to 5 -meC were seen (Fig. 3). Only two cases $(0.6 \%)$ had a positive reaction to DNMT1 in the stromal cells.

\section{Differences in clinicopathologic factors according to the expression status of epigenetic methylation-related proteins}

When clinicopathologic parameters were evaluated according to the expression status of epigenetic methylation-related proteins, expression of DNMT1 in malignant cells was associated with higher histological grade, ER negativity, PR negativity, and higher Ki-67 LI $(\mathrm{p}<0.001)$ (Fig. 4).

Impact of epigenetic methylation-related protein expression in breast cancer on patient prognosis

Univariate analysis of the impact of epigenetic methylation-related protein expression on breast cancer patient prognosis showed that high expression of DNMT1 in malignant cells correlated with shorter OS $(\mathrm{p}=0.041)$ 
Table 2 Clinicopathological characteristics of patients by breast cancer molecular subtype

\begin{tabular}{|c|c|c|c|c|c|c|}
\hline Parameter & $\begin{array}{l}\text { Total }(n=348) \\
(\%)\end{array}$ & $\begin{array}{l}\text { Luminal A }(n=162) \\
(\%)\end{array}$ & $\begin{array}{l}\text { Luminal B }(n=84) \\
(\%)\end{array}$ & $\begin{array}{l}\text { HER-2 }(n=27) \\
(\%)\end{array}$ & $\begin{array}{l}\text { TNBC }(n=75) \\
(\%)\end{array}$ & $P$ value \\
\hline \multicolumn{7}{|l|}{ Age (years) } \\
\hline$\leq 50$ & $202(58.0)$ & $94(58.0)$ & $55(65.5)$ & $13(48.1)$ & $40(53.3)$ & \multirow[t]{2}{*}{0.299} \\
\hline$>50$ & $146(46.7)$ & $68(42.0)$ & $29(34.5)$ & $14(51.9)$ & $35(46.7)$ & \\
\hline \multicolumn{7}{|l|}{ Histological grade } \\
\hline$|/| \mid$ & $242(69.5)$ & $147(90.7)$ & $53(63.1)$ & $12(44.4)$ & $30(40.0)$ & \multirow[t]{2}{*}{$<0.001$} \\
\hline III & $106(30.5)$ & $15(9.3)$ & $31(36.9)$ & 15 (55.6) & $45(60.0)$ & \\
\hline \multicolumn{7}{|l|}{ Tumor stage } \\
\hline $\mathrm{T} 1$ & $182(52.3)$ & $96(59.3)$ & $42(50.0)$ & $13(48.1)$ & $31(41.3)$ & \multirow[t]{2}{*}{0.068} \\
\hline $\mathrm{T} 2 / \mathrm{T} 3$ & $166(47.7)$ & $66(40.7)$ & $42(50.0)$ & $14(51.9)$ & $44(58.7)$ & \\
\hline \multicolumn{7}{|l|}{ Nodal metastasis } \\
\hline Absent & $208(59.8)$ & $94(58.0)$ & $48(57.1)$ & $17(63.0)$ & $49(65.3)$ & \multirow[t]{2}{*}{0.676} \\
\hline Present & $140(40.2)$ & $68(42.0)$ & $36(42.9)$ & $10(37.0)$ & $26(34.7)$ & \\
\hline \multicolumn{7}{|c|}{ Estrogen-receptor status } \\
\hline Negative & $107(30.7)$ & $2(1.2)$ & $3(3.6)$ & $27(100.0)$ & $75(100.0)$ & \multirow[t]{2}{*}{$<0.001$} \\
\hline Positive & $241(69.3)$ & $160(98.8)$ & $81(96.4)$ & $0(0.0)$ & $0(0.0)$ & \\
\hline \multicolumn{7}{|c|}{ Progesterone-receptor status } \\
\hline Negative & $149(42.8)$ & $20(12.3)$ & $27(32.1)$ & $27(100.0)$ & $75(100.0)$ & \multirow[t]{2}{*}{$<0.001$} \\
\hline Positive & $199(57.2)$ & $142(87.7)$ & $57(67.9)$ & $0(0.0)$ & $0(0.0)$ & \\
\hline \multicolumn{7}{|l|}{ HER-2 status } \\
\hline Negative & $280(80.5)$ & $162(100.0)$ & $43(51.2)$ & $0(0.0)$ & $75(100.0)$ & \multirow[t]{2}{*}{$<0.001$} \\
\hline Positive & $68(19.5)$ & $0(0.0)$ & $41(48.8)$ & $27(100.0)$ & $0(0.0)$ & \\
\hline \multicolumn{7}{|l|}{ Ki-67 LI (\%) } \\
\hline$\leq 14$ & $213(61.2)$ & $162(100.0)$ & $24(28.6)$ & $13(48.1)$ & $14(18.7)$ & \multirow[t]{2}{*}{$<0.001$} \\
\hline$>14$ & $135(38.8)$ & $0(0.0)$ & $60(71.4)$ & $14(51.9)$ & $61(81.3)$ & \\
\hline \multicolumn{7}{|l|}{ Stromal phenotype } \\
\hline Desmoplastic type & $97(27.9)$ & $42(25.9)$ & $34(40.5)$ & $6(22.2)$ & $15(20.0)$ & \multirow[t]{4}{*}{$<0.001$} \\
\hline Inflammatory type & $30(8.6)$ & $3(1.9)$ & $4(4.8)$ & $3(11.1)$ & $20(26.7)$ & \\
\hline Normal-like type & $16(4.6)$ & $7(4.3)$ & $4(4.8)$ & $0(0.0)$ & $5(6.7)$ & \\
\hline Sclerotic type & $205(58.9)$ & $110(67.9)$ & $42(50.0)$ & $18(66.7)$ & $35(46.7)$ & \\
\hline Tumor recurrence & $32(9.2)$ & $10(6.2)$ & $8(9.5)$ & $3(11.1)$ & $11(14.7)$ & 0.204 \\
\hline No. of patient deaths & $35(10.1)$ & $9(5.6)$ & $9(10.7)$ & $4(14.8)$ & $13(17.3)$ & 0.033 \\
\hline $\begin{array}{l}\text { Duration of clinical } \\
\text { follow-up (months, } \\
\text { mean } \pm \text { SD) }\end{array}$ & $77.0 \pm 33.8$ & $78.4 \pm 31.9$ & $75.2 \pm 33.5$ & $77.7 \pm 39.5$ & $75.7 \pm 36.3$ & 0.884 \\
\hline
\end{tabular}

TNBC triple negative breast cancer

(Table 5 and Fig. 5a); however, the association was not significant in multivariate Cox analysis (Table 6). Univariate analysis of the impact of epigenetic methylationrelated protein expression by stromal phenotype on patient prognosis showed that high expression of DNMT1in malignant cells tended to be associated with shorter OS in sclerotic type ( $p=0.052$, Fig. $5 b)$.

Western blot analysis of the epigenetic methylation-related protein in breast cancer according to the molecular subtype Western blot analysis was performed to confirm the expression of epigenetic methylation-related protein according to the breast cancer molecular subtypes. Protein expressions of DNMT1 and ISL-1 were higher in TNBC and relatively lower in the remaining subtypes (Fig. 6).

\section{Discussion}

We assessed the expression status of epigenetic methylation-related proteins in breast cancer. Tumor expression of DNMT1 differed with breast cancer molecular subtype. Our results identified high tumor expression of DNMT1 in TNBC and low tumor expression of DNMT 1 in luminal A type, concordant with a previous study in 
Table 3 Expression of epigenetic methylation-related proteins by breast cancer subtype

\begin{tabular}{|c|c|c|c|c|c|c|}
\hline Parameter & $\begin{array}{l}\text { Total } \\
(\mathrm{n}=348)(\%)\end{array}$ & $\begin{array}{l}\text { Luminal } A \\
(n=162)(\%)\end{array}$ & $\begin{array}{l}\text { Luminal B } \\
(n=84)(\%)\end{array}$ & $\begin{array}{l}\text { HER-2 } \\
(n=27)(\%)\end{array}$ & $\begin{array}{l}\text { TNBC } \\
(n=75)(\%)\end{array}$ & $P$ value \\
\hline \multicolumn{7}{|l|}{ 5-meC (T) } \\
\hline Low & 44 (12.6) & $27(16.7)$ & $8(9.5)$ & $3(11.1)$ & $6(8.0)$ & 0.200 \\
\hline High & $304(87.4)$ & $135(83.3)$ & $76(90.5)$ & 24 (88.9) & 69 (92.0) & \\
\hline \multicolumn{7}{|l|}{ 5-meC (S) } \\
\hline Low & $14(4.0)$ & $7(4.3)$ & $2(2.4)$ & $1(3.7)$ & $4(5.3)$ & 0.810 \\
\hline High & $334(96.0)$ & 155 (95.7) & 82 (97.6) & $26(96.3)$ & 71 (94.7) & \\
\hline \multicolumn{7}{|l|}{ DNMT1 (T) } \\
\hline Low & $316(90.8)$ & $161(99.4)$ & 77 (91.7) & 24 (88.9) & $54(72.0)$ & $<0.001$ \\
\hline High & $32(9.2)$ & $1(0.6)$ & $7(8.3)$ & $3(11.1)$ & $21(28.0)$ & \\
\hline \multicolumn{7}{|l|}{ DNMT1 (S) } \\
\hline Negative & $346(99.4)$ & $162(100.0)$ & $84(100.0)$ & $27(100.0)$ & 73 (97.3) & 0.062 \\
\hline Positive & $2(0.6)$ & $0(0.0)$ & $0(0.0)$ & $0(0.0)$ & $2(2.7)$ & \\
\hline \multicolumn{7}{|l|}{ ISL-1 (T) } \\
\hline Negative & $343(98.6)$ & $159(98.1)$ & $84(100.0)$ & $27(100.0)$ & 73 (97.3) & 0.455 \\
\hline Positive & $5(1.4)$ & $3(1.9)$ & $0(0.0)$ & $0(0.0)$ & $2(2.7)$ & \\
\hline
\end{tabular}

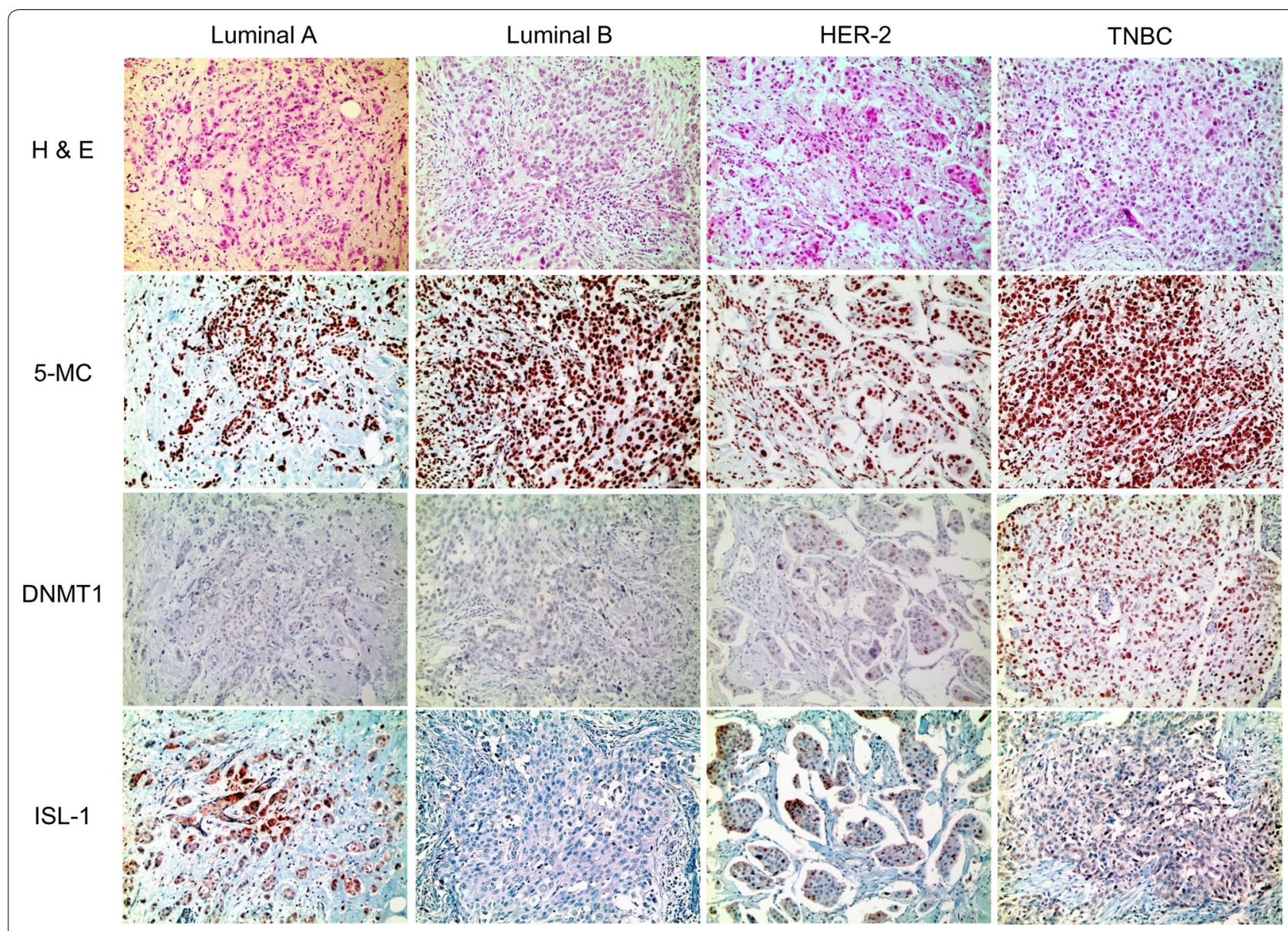

Fig. 1 Expression of epigenetic methylation-related proteins by breast cancer molecular subtype. Expression of DNMT1 in malignant cells is higher in TNBC and lower in luminal A. Expression of DNMT1 in stromal cells is apparent in TNBC only 
Table 4 Expression of epigenetic methylation-related proteins by stromal phenotype

\begin{tabular}{|c|c|c|c|c|c|c|}
\hline Parameter & $\begin{array}{l}\text { Total } \\
(n=348)(\%)\end{array}$ & $\begin{array}{l}\text { Desmoplastic type } \\
(\mathrm{n}=97)(\%)\end{array}$ & $\begin{array}{l}\text { Inflammatory type } \\
(n=30)(\%)\end{array}$ & $\begin{array}{l}\text { Normal-like type } \\
(n=16)(\%)\end{array}$ & $\begin{array}{l}\text { Sclerotic type } \\
(n=205)(\%)\end{array}$ & $P$ value \\
\hline \multicolumn{7}{|l|}{ 5-meC (T) } \\
\hline Low & 44 (12.6) & $8(8.2)$ & $2(6.7)$ & $0(0.0)$ & $34(16.6)$ & 0.049 \\
\hline High & $304(87.4)$ & $89(91.8)$ & $28(93.3)$ & $16(100.0)$ & $171(83.4)$ & \\
\hline \multicolumn{7}{|l|}{ 5-meC (S) } \\
\hline Low & $14(4.0)$ & $3(3.1)$ & $1(3.3)$ & $0(0.0)$ & $10(4.9)$ & 0.726 \\
\hline High & $334(96.0)$ & 94 (96.9) & $29(96.7)$ & $16(100.0)$ & $195(95.1)$ & \\
\hline \multicolumn{7}{|l|}{ DNMT1 (T) } \\
\hline Low & $316(90.8)$ & 88 (90.7) & $21(70.0)$ & 14 (87.5) & $193(94.1)$ & $<0.001$ \\
\hline High & $32(9.2)$ & $9(9.3)$ & $9(30.0)$ & $2(12.5)$ & $12(5.9)$ & \\
\hline \multicolumn{7}{|l|}{ DNMT1 (S) } \\
\hline Negative & $346(99.4)$ & $97(100.0)$ & $29(96.7)$ & $16(100.0)$ & $204(99.5)$ & 0.197 \\
\hline Positive & $2(0.6)$ & $0(0.0)$ & $1(3.3)$ & $0(0.0)$ & $1(0.5)$ & \\
\hline \multicolumn{7}{|l|}{ ISL-1 (T) } \\
\hline Negative & 343 (98.6) & $96(99.0)$ & $29(96.7)$ & $16(100.0)$ & $202(98.5)$ & 0.775 \\
\hline Positive & $5(1.4)$ & $1(1.0)$ & $1(3.3)$ & $0(0.0)$ & $3(1.5)$ & \\
\hline
\end{tabular}

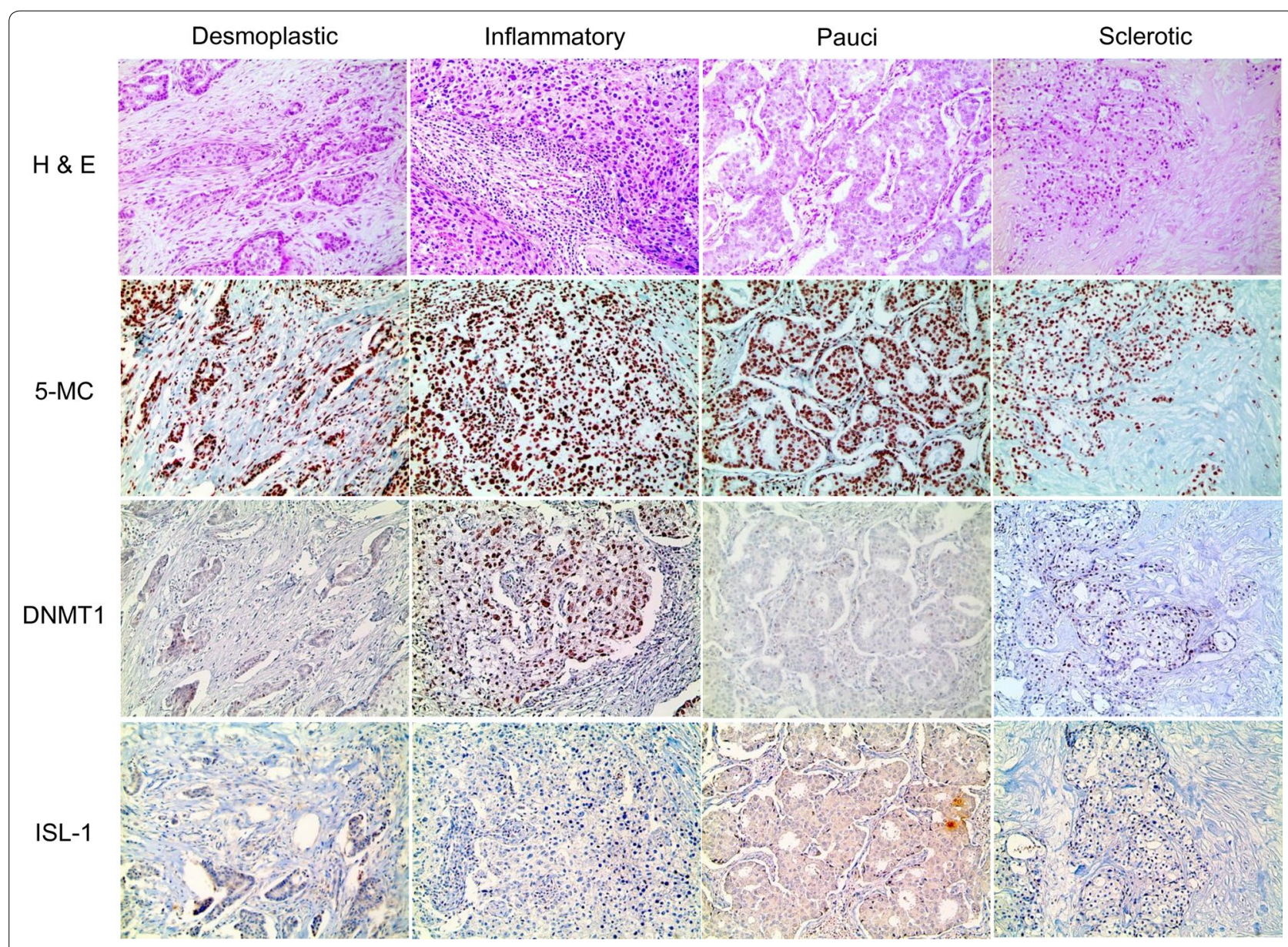

Fig. 2 Expression of epigenetic methylation-related proteins by breast cancer stromal phenotype. 5-meC expression in malignant cells is highly expressed in normal-like type, with lower expression in sclerotic type. In addition, expression of DNMT1 in malignant cells is higher in inflammatory type and lower in sclerotic type 


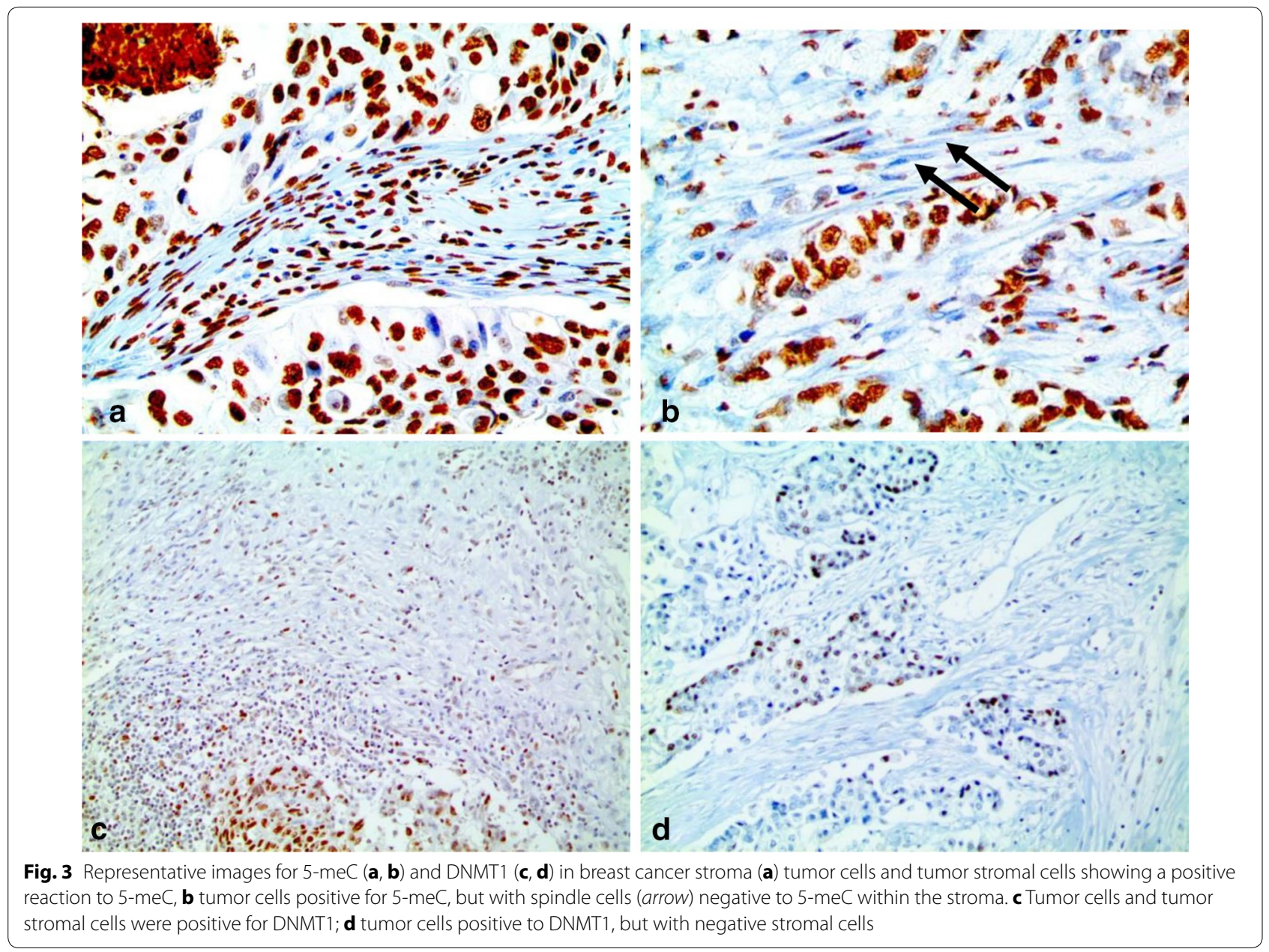

which DNMT1 expression was reported to be increased in breast cancer compared to other benign lesions, especially in ER-negative breast cancer [4]. DNMT1 expression in our study was also correlated with ER negativity and PR negativity. A possible mechanism of higher expression of DNMT1 in TNBC might be association of TNBC with cancer stem cells. TNBC is highly correlated with cancer stem cell characteristics and DNMT1 is essential for cancer cell maintenance, resulting in high expression of DNMT1 in TNBC [3]. Our results showed that the expression of epigenetic methylationrelated proteins differ by stromal phenotype. Tumor expression of DNMT1 was higher in inflammatory stromal type samples compared to other subtypes. Previous studies reported that IL-6 increases nuclear translocation of DNMT1 through phosphorylation of the nuclear localization sequence [12]. IL-6 is mainly secreted by tumor-infiltrating lymphocytes [13] and tumor-associated macrophages [14], explaining the increased expression of DNMT1 in the inflammatory stromal subtype. These results imply that stromal subtype might affect the methylation status of breast cancer. However, further study is needed to test this hypothesis.

DNMT1 and 5-meC were expressed in both malignant cells and stromal cells, although with different expression status; 5-meC was expressed in the stromal cells in $96 \%$, whereas DNMT1 was expressed in only less than $1 \%$. An important factor in the tumor microenvironment is cancer-associated fibroblasts (CAFs). Epigenetic alteration can occur in CAFs, as seen by differences in specific DNA methylation patterns between tumor-associated stroma and non-tumor stroma on methylation pattern analysis $[15,16]$. About $4 \%$ of the cases in our study had spindle-shaped stromal cells that 


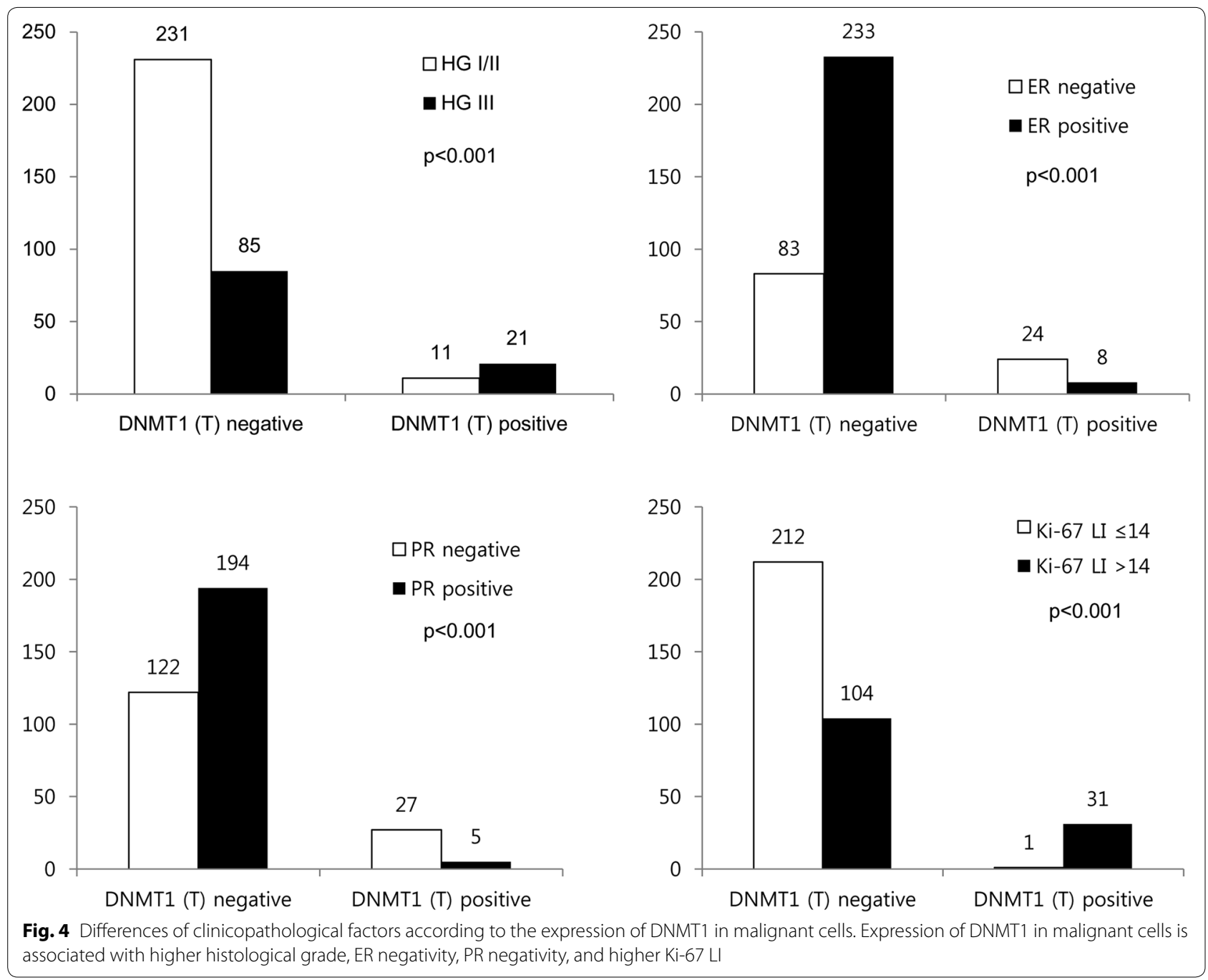

were non-immunoreactive to 5-meC. These 5-meCnegative spindle cells are presumed to be hypomethylated CAFs, but this possibility needs to be tested with further study. The expression of DNMT1 was mostly negative in the tumor stroma, compatible with previous results showing no or low immunohistochemical reaction to DNMT1 in the tumor stroma and normal stroma [17].

We found an association between high tumor expression of DNMT1 and shorter OS, concordant with previous studies in which high expression of DNMT1 was associated with poor prognosis in malignant lymphoma [10], renal cell carcinoma [18], pancreatic cancer [19], and bladder cancer [20]. The clinical significance of this result is the possibility of therapy targeting epigenetic methylation-related proteins such as DNMT1. Currently, the possibility of DNMT1 as a new target is being explored for many tumors [21-24] and DNMT1 can be a new target for breast cancer as well. Since the expression degree of DNMT1 differs by molecular and stromal subtypes, DNMT1 may very well be a new therapeutic target for breast cancer type with high DNMT1 expression.

\section{Conclusion}

In conclusion, DNMT1 is differentially expressed in breast cancer according to the molecular and stromal subtypes, and it is most highly expressed in TNBC and inflammatory stromal types. 
Table 5 Univariate analysis of the impact of epigenetic methylation-related protein expression on breast cancer patient prognosis by log-rank test

\begin{tabular}{|c|c|c|c|c|c|}
\hline \multirow[t]{2}{*}{ Parameter } & \multirow{2}{*}{$\begin{array}{l}\text { Number of } \\
\text { patients/recurrence/ } \\
\text { death }\end{array}$} & \multicolumn{2}{|c|}{ Disease-free survival } & \multicolumn{2}{|l|}{ Overall survival } \\
\hline & & $\begin{array}{l}\text { Mean survival } \\
(95 \% \mathrm{Cl}) \text { months }\end{array}$ & $P$ value & $\begin{array}{l}\text { Mean survival } \\
(95 \% \mathrm{Cl}) \text { months }\end{array}$ & $P$ value \\
\hline \multicolumn{6}{|l|}{ 5-meC (T) } \\
\hline Low & $44 / 2 / 3$ & $131(124-138)$ & 0.206 & $132(124-141)$ & 0.370 \\
\hline High & $304 / 30 / 32$ & $126(121-130)$ & & $127(123-132)$ & \\
\hline \multicolumn{6}{|l|}{ 5-meC (S) } \\
\hline Low & $14 / 1 / 1$ & $129(115-143)$ & 0.709 & $131(116-145)$ & 0.659 \\
\hline High & $334 / 31 / 34$ & $127(122-131)$ & & $128(124-132)$ & \\
\hline \multicolumn{6}{|l|}{ DNMT1 (T) } \\
\hline Low & $316 / 28 / 29$ & $127(123-131)$ & 0.348 & $129(126-133)$ & 0.041 \\
\hline High & $23 / 4 / 6$ & $115(100-129)$ & & $111(95-128)$ & \\
\hline \multicolumn{6}{|l|}{ DNMT1 (S) } \\
\hline Negative & $346 / 32 / 35$ & N/A & N/A & N/A & N/A \\
\hline Positive & $2 / 0 / 0$ & N/A & & N/A & \\
\hline \multicolumn{6}{|l|}{ ISL-1 (T) } \\
\hline Negative & $343 / 32 / 34$ & N/A & N/A & $128(124-132)$ & 0.436 \\
\hline Positive & $5 / 0 / 1$ & N/A & & $63(60-66)$ & \\
\hline
\end{tabular}

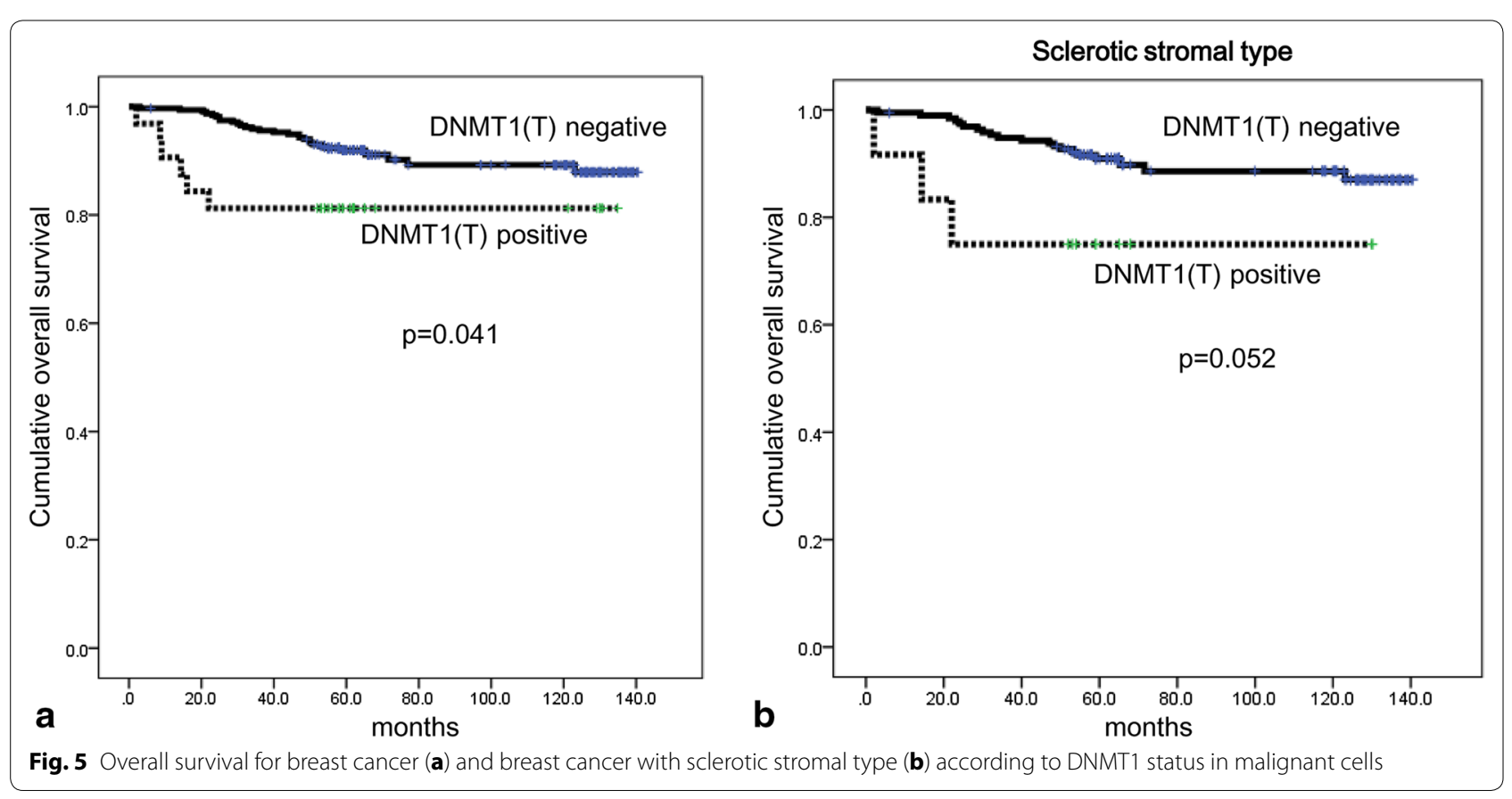


Table 6 Multivariate analysis of breast cancer survival

\begin{tabular}{|c|c|c|c|c|c|c|}
\hline \multirow[t]{2}{*}{ Included parameters } & \multicolumn{3}{|c|}{ Disease-free survival } & \multicolumn{3}{|c|}{ Overall survival } \\
\hline & Hazard ratio & $95 \% \mathrm{Cl}$ & $P$ value & Hazard ratio & $95 \% \mathrm{Cl}$ & $P$ value \\
\hline \multicolumn{7}{|l|}{ Tstage } \\
\hline $\mathrm{T} 1$ versus $\mathrm{T} 2-3$ & 2.376 & $1.064-5.305$ & 0.035 & 1.714 & $0.826-3.556$ & 0.148 \\
\hline \multicolumn{7}{|l|}{ N stage } \\
\hline No versus N1-3 & 2.994 & $1.424-6.296$ & 0.004 & 2.127 & $1.061-4.262$ & 0.033 \\
\hline \multicolumn{7}{|l|}{ Histologic grade } \\
\hline |/II versus III & 1.214 & $0.515-2.859$ & 0.658 & 0.785 & $0.353-1.747$ & 0.553 \\
\hline \multicolumn{7}{|l|}{ ER status } \\
\hline Negative versus positive & 0.544 & $0.197-1.507$ & 0.242 & 0.650 & $0.259-1.632$ & 0.359 \\
\hline \multicolumn{7}{|l|}{ PR status } \\
\hline Negative versus positive & 0.768 & $0.275-2.147$ & 0.615 & 0.436 & $0.164-1.158$ & 0.096 \\
\hline \multicolumn{7}{|l|}{ HER-2 status } \\
\hline Negative versus positive & 0.967 & $0.406-2.307$ & 0.940 & 1.050 & $0.463-2.381$ & 0.907 \\
\hline \multicolumn{7}{|l|}{ Ki-67 LI } \\
\hline$\leq 14$ versus $>14$ & 0.764 & $0.308-1.899$ & 0.563 & 0.805 & $0.340-1.901$ & 0.620 \\
\hline \multicolumn{7}{|l|}{ 5-meC (T) } \\
\hline Low versus high & 3.117 & $0.728-13.35$ & 0.126 & 1.828 & $0.543-6.155$ & 0.330 \\
\hline \multicolumn{7}{|l|}{$5-\mathrm{meC}(\mathrm{S})$} \\
\hline Low versus high & 1.498 & $0.201-11.13$ & 0.693 & 1.515 & $0.203-11.31$ & 0.686 \\
\hline \multicolumn{7}{|l|}{ DNMT1 (T) } \\
\hline Low versus high & 0.937 & $0.289-3.037$ & 0.913 & 1.473 & $0.538-4.036$ & 0.451 \\
\hline \multicolumn{7}{|l|}{ DNMT1 (S) } \\
\hline Negative versus positive & N/A & N/A & N/A & N/A & N/A & N/A \\
\hline \multicolumn{7}{|l|}{ ISL-1 (T) } \\
\hline Negative versus positive & N/A & N/A & N/A & 2.075 & $0.270-15.96$ & 0.483 \\
\hline
\end{tabular}

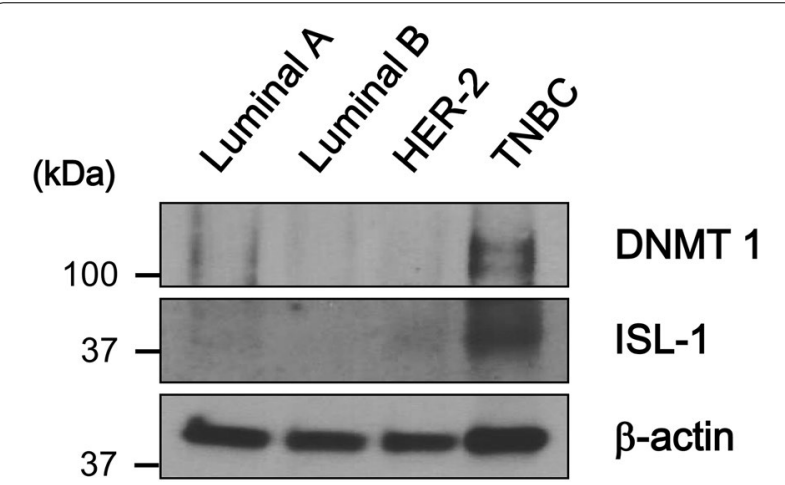

Fig. 6 Western blot analysis of DNMT1 and ISL-1 in FFPE breast cancer tissue according to the molecular subtype. Protein expressions of DNMT1 and ISL-1 are higher in TNBC and relatively lower in the remaining subtypes

\section{Abbreviations}

DNMT: DNA methyltransferase; 5-MeC: 5-methylcytosine; ISL-1: insulin gene enhancer binding protein-1, 2; H\&E: hematoxylin and eosin; ER: estrogen receptor; PR: progesterone receptor.

\section{Authors' contributions}

ES participated in the design of the study, performed the statistical analysis, and carried out the immunoassays. YL participated in its design and western blot analysis. JSK conceived the study, participated in its design and coordination, and helped to draft the manuscript. All authors read and approved the final manuscript.

\section{Author details}

${ }^{1}$ Department of Pathology, CHA Gangnam Medical Center, CHA University, Seoul, South Korea. ${ }^{2}$ Department of Pathology, Yonsei University College of Medicine, 50 Yonsei-ro, Seodaemun-gu, Seoul 120-752, South Korea.

\section{Acknowledgements}

This study was supported by a Grant from the National R\&D Program for Cancer Control, Ministry of Health and Welfare, Republic of Korea (1420080). This research was supported by Basic Science Research Program through the National Research Foundation of Korea (NRF) funded by the Ministry of Science, ICT and Future Planning (2015R1A1A1A05001209).

\section{Competing interests}

The authors declare that they have no competing interests.

Received: 9 September 2015 Accepted: 28 March 2016

Published online: 12 April 2016 


\section{References}

1. Jones PA. DNA methylation and cancer. Oncogene. 2002;21:5358-60.

2. Siedlecki P, Zielenkiewicz P. Mammalian DNA methyltransferases. Acta Biochim Pol. 2006;53:245-56.

3. Pathania R, Ramachandran S, Elangovan S, Padia R, Yang P, Cinghu S, Veeranan-Karmegam R, Arjunan P, Gnana-Prakasam JP, Sadanand F, Pei L, Chang CS, Choi JH, Shi H, Manicassamy S, Prasad PD, Sharma S, Ganapathy $V$, Jothi $R$, Thangaraju M. DNMT1 is essential for mammary and cancer stem cell maintenance and tumorigenesis. Nat Commun. 2015;6:6910.

4. Yu Z, Xiao Q, Zhao L, Ren J, Bai X, Sun M, Wu H, Liu X, Song Z, Yan Y, Mi $X$, Wang $E$, Jin F, Wei M. DNA methyltransferase 1/3a overexpression in sporadic breast cancer is associated with reduced expression of estrogen receptor-alpha/breast cancer susceptibility gene 1 and poor prognosis. Mol Carcinog. 2015;54(9):707-19.

5. Perou CM, Sorlie T, Eisen MB, van de Rijn M, Jeffrey SS, Rees CA, Pollack JR, Ross DT, Johnsen H, Akslen LA, Fluge O, Pergamenschikov A, Williams C, Zhu SX, Lonning PE, Borresen-Dale AL, Brown PO, Botstein D. Molecular portraits of human breast tumours. Nature. 2000;406:747-52.

6. Sorlie T, Perou CM, Tibshirani R, Aas T, Geisler S, Johnsen H, Hastie T, Eisen MB, van de Rijn M, Jeffrey SS, Thorsen T, Quist H, Matese JC, Brown PO, Botstein D, Lonning PE, Borresen-Dale AL. Gene expression patterns of breast carcinomas distinguish tumor subclasses with clinical implications. Proc Natl Acad Sci USA. 2001;98:10869-74.

7. Elston CW, Ellis IO. Pathological prognostic factors in breast cancer. I. The value of histological grade in breast cancer: experience from a large study with long-term follow-up. Histopathology. 1991;19:403-10.

8. Hammond ME, Hayes DF, Dowsett M, Allred DC, Hagerty KL, Badve S, Fitzgibbons PL, Francis G, Goldstein NS, Hayes M, Hicks DG, Lester S, Love R, Mangu PB, McShane L, Miller K, Osborne CK, Paik S, Perlmutter J, Rhodes A, Sasano H, Schwartz JN, Sweep FC, Taube S, Torlakovic EE, Valenstein P, Viale G, Visscher D, Wheeler T, Williams RB, Wittliff JL, Wolff AC. American society of clinical oncology/college of american pathologists guideline recommendations for immunohistochemical testing of estrogen and progesterone receptors in breast cancer. J Clin Oncol. 2010;28:2784-95.

9. Wolff AC, Hammond ME, Schwartz JN, Hagerty KL, Allred DC, Cote RJ, Dowsett M, Fitzgibbons PL, Hanna WM, Langer A, McShane LM, Paik S, Pegram MD, Perez EA, Press MF, Rhodes A, Sturgeon C, Taube SE, Tubbs $\mathrm{R}$, Vance $\mathrm{GH}$, van de Vijver M, Wheeler TM, Hayes DF. American society of clinical oncology/college of american pathologists guideline recommendations for human epidermal growth factor receptor 2 testing in breast cancer. J Clin Oncol. 2007;25:118-45.

10. Zhao H, Zhang LE, Guo S, Yuan T, Xia B, Zhang L, Zhang Y. Overexpression of DNA methyltransferase 1 as a negative independent prognostic factor in primary gastrointestinal diffuse large B-cell lymphoma treated with CHOP-like regimen and rituximab. Oncol Lett. 2015;9:2307-12.

11. Goldhirsch A, Wood WC, Coates AS, Gelber RD, Thurlimann B, Senn HJ. Strategies for subtypes-dealing with the diversity of breast cancer: highlights of the St. Gallen international expert consensus on the primary therapy of early breast cancer 2011. Ann Oncol. 2011;22:1736-47.

12. Hodge DR, Cho E, Copeland TD, Guszczynski T, Yang E, Seth AK, Farrar WL. IL-6 enhances the nuclear translocation of DNA cytosine-5-methyltransferase 1 (DNMT1) via phosphorylation of the nuclear localization sequence by the AKT kinase. Cancer Genomics Proteomics. 2007:4:387-98.

13. Kovacsovics-Bankowski M, Chisholm L, Vercellini J, Tucker CG, Montler R, Haley D, Newell P, Ma J, Tseng P, Wolf R, Vetto JT, Hammill C, Hansen P, Weinberg AD. Detailed characterization of tumor infiltrating lymphocytes in two distinct human solid malignancies show phenotypic similarities. J Immunother Cancer. 2014;2:38.

14. Xu H, Lai W, Zhang Y, Liu L, Luo X, Zeng Y, Wu H, Lan Q, Chu Z. Tumorassociated macrophage-derived IL- 6 and IL-8 enhance invasive activity of LoVo cells induced by PRL-3 in a KCNN4 channel-dependent manner. BMC Cancer. 2014;14:330.

15. Cunha GR, Hayward SW, Wang YZ. Role of stroma in carcinogenesis of the prostate. Differentiation. 2002;70:473-85.

16. Rodriguez-Canales J, Hanson JC, Tangrea MA, Erickson HS, Albert PS, Wallis BS, Richardson AM, Pinto PA, Linehan WM, Gillespie JW, Merino MJ, Libutti SK, Woodson KG, Emmert-Buck MR, Chuaqui RF. Identification of a unique epigenetic sub-microenvironment in prostate cancer. J Pathol. 2007;211:410-9.

17. Ostman A. Cancer-associated fibroblasts: recent developments and emerging challenges. Semin Cancer Biol. 2014;25:1-2.

18. Li M, Wang Y, Song Y, Bu R, Yin B, Fei X, Guo Q, Wu B. Aberrant DNA methyltransferase 1 expression in clear cell renal cell carcinoma development and progression. Chin J Cancer Res. 2014;26:371-81.

19. Zhang JJ, Zhu Y, Zhu Y, Wu JL, Liang WB, Zhu R, Xu ZK, Du Q, Miao Y. Association of increased DNA methyltransferase expression with carcinogenesis and poor prognosis in pancreatic ductal adenocarcinoma. Clin Transl Oncol. 2012;14:116-24.

20. Wu CT, Wu CF, Lu CH, Lin CC, Chen WC, Lin PY, Chen MF. Expression and function role of DNA methyltransferase 1 in human bladder cancer. Cancer. 2011:117:5221-33.

21. Amato RJ, Stephenson J, Hotte S, Nemunaitis J, Belanger K, Reid G, Martell RE. MG98, a second-generation DNMT1 inhibitor, in the treatment of advanced renal cell carcinoma. Cancer Invest. 2012;30:415-21.

22. Mutze K, Langer R, Schumacher F, Becker K, Ott K, Novotny A, Hapfelmeier A, Hofler $\mathrm{H}$, Keller G. DNA methyltransferase 1 as a predictive biomarker and potential therapeutic target for chemotherapy in gastric cancer. Eur J Cancer. 2011:47:1817-25.

23. Subramaniam D, Thombre R, Dhar A, Anant S. DNA methyltransferases: a novel target for prevention and therapy. Front Oncol. 2014;4:80

24. Thottassery JV, Sambandam V, Allan PW, Maddry JA, Maxuitenko YY, Tiwar K, Hollingshead M, Parker WB. Novel DNA methyltransferase-1 (DNMT1) depleting anticancer nucleosides, 4'-thio-2'-deoxycytidine and 5-aza-4' thio-2'-deoxycytidine. Cancer Chemother Pharmacol. 2014;74:291-302.

\section{Submit your next manuscript to BioMed Central and we will help you at every step:}

- We accept pre-submission inquiries

- Our selector tool helps you to find the most relevant journal

- We provide round the clock customer support

- Convenient online submission

- Thorough peer review

- Inclusion in PubMed and all major indexing services

- Maximum visibility for your research

Submit your manuscript at www.biomedcentral.com/submit
O Biomed Central 